\title{
Relational Embeddedness and BOP-Oriented Dynamic Capability-A Multi-Case Study
}

\author{
Yina Zhang ${ }^{1,+}{ }^{\mathbb{D}}$, Jiancheng Long ${ }^{1}$ and Wu Zhao ${ }^{2, *,+}+\mathbb{D}$ \\ 1 School of Economics and Management, Xidian University, No. 266 Xinglong Section, Xifeng Road, \\ Xi'an 710126, China; ynzhang_3@stu.xidian.edu.cn (Y.Z.); jchlong@xidian.edu.cn (J.L.) \\ 2 School of Marxism, Xidian University, No. 266 Xinglong Section, Xifeng Road, Xi'an 710126, China \\ * Correspondence: zhsxwu@xidian.edu.cn \\ + Both authors are contributed equally to this paper.
}

Citation: Zhang, Y.; Long, J.; Zhao, W. Relational Embeddedness and BOP-Oriented Dynamic Capability-A Multi-Case Study. Sustainability 2021, 13, 6065. https:// doi.org/10.3390/su13116065

Academic Editor: Bruce Morley

Received: 22 April 2021

Accepted: 25 May 2021

Published: 27 May 2021

Publisher's Note: MDPI stays neutral with regard to jurisdictional claims in published maps and institutional affiliations.

Copyright: (c) 2021 by the authors. Licensee MDPI, Basel, Switzerland. This article is an open access article distributed under the terms and conditions of the Creative Commons Attribution (CC BY) license (https:/ / creativecommons.org/licenses/by/ $4.0 /)$.

\begin{abstract}
The Bottom of the Pyramid (BOP) market is composed of a large number of low-income groups around the world and contains huge wealth that has not yet been discovered. An exploratory multi-case study was conducted to analyze the impact of relational embeddedness on dynamic capability (DC). On the basis of theoretical presuppositions, based on the intra- and inter-case analysis of six companies in the China BOP market, this paper explores how relational embeddedness affects the DC of companies through exploitative learning and exploratory learning. Twelve research propositions are presented and the theoretical framework of relational embeddedness affecting the DC of enterprises is constructed. The study found that mutual trust and reciprocity norms in the BOP cooperation network can promote the acquisition and utilization of existing knowledge and new knowledge of the enterprise, thereby enhancing the enterprise environmental sensing, environmental adaptive, and environmental shaping capabilities.
\end{abstract}

Keywords: relational embeddedness; exploitative learning; exploratory learning; dynamic capability; BOP; case study

\section{Introduction}

The World Bank World Development Report 2000/2001: Attacking Poverty outlines an ambitious goal to halve world poverty levels by the year 2015 (World Bank 2019) [1]. Fast forward to 2017, and poverty remains one of the greatest challenges the world faces. With around three billion people [2] living at the Base/Bottom of the Pyramid (BOP), scholars, government officials, and business practitioners from a range of different disciplines (e.g., Ansari et al., 2012; Khavul and Bruton 2013; London and Hart 2004; Prahalad and Hart 2002; Slawinski, 2012; Kantar Research Report, 2015) [3-8] have sought to conceive of ways to alleviate it. The BOP strategy proposed by Prahalad and Hart points out that the vast low-income groups that are rarely paid attention to by business actually contain huge wealth [6]. By including the people at the BOP in the market economy, entrepreneurs can generate profits while simultaneously alleviating poverty (Hart and London, 2005) [9]. Nevertheless, BOP markets are associated with unique challenges (London and Hart, 2004) [5] and high levels of uncertainty (Alvarez and Barney, 2006; Kolk, Rivera-Santos, and Rufín, 2014) [10,11], and the institutional contexts of these markets often provide little support for economic activities (Kolk et al., 2014; Khanna et al., 2005) [11,12]. These are all characteristics of the BOP context that must be overcome. Overall, Hart (2015) [13] argues that most BOP ventures and corporate initiatives over the past decade have either failed outright or achieved merely moderate success at great cost. Due to the huge differences between the BOP market environment and the Top of the Pyramid (TOP) market that companies are familiar with, such as absence of formal capital markets, low educated workforce, poorly developed public infrastructure, informal governance mechanisms (Webb et al., 2010) [14], and lack of intellectual property protection (De Soto, 2000) [15]. 
The obstacles and constraints of the BOP market do not belong to the scope of business. It is difficult for enterprises to completely rely on traditional business skills to overcome them. Being embedded in a cooperation network with specific relationships and structures established by non-traditional partners such as local government departments, community organizations, intermediaries, and the poor themselves (hereinafter referred to as BOP network) is the key to success (Brugmann and Prahalad, 2007; Clarke and Mark, 2010; Rivera-Santos and Rufin, 2010; Ramachandran, 2011) [16-19]. At the same time, due to the highly heterogeneous goals, resources, and capabilities of each participant, facing the ever-changing environment, network members need to adjust in time during interaction to improve the effectiveness of cooperation, and the BOP network as a whole will show ever-evolving dynamics. Døving and Gooderham proposed that any single connection with an external partner is difficult to deal with in a dynamic environment [20]. Therefore, the diversity or scope of relationships between enterprises can be regarded as an important manifestation of DC, helping enterprises to obtain diverse resources and capabilities in the network. Adopting the research perspective of network embeddedness, in-depth analysis of the impact of various characteristics of corporate relational embeddedness in the network on DC will help companies find ways to improve DC in an open environment, and guide companies to build the BOP network that adapts to dynamic environment.

The current research gaps are as follows: (1) Although the existing theoretical research outlines the characteristics of network resources and the competitive advantages it brings to enterprises, it does not address what mechanism is used for the enterprise dynamic capability that lacks in-depth exploration for the relational embeddedness of enterprises in the BOP network. (2) In terms of DC, existing research mainly focuses on the TOP market such as the technology innovation network and little attention is paid to the BOP market. The constitutional dimension and internal mechanism of DC in the BOP market need further study. (3) Localization-related case studies for local cases in China are still limited. In this paper, we bring together the theoretical lenses of social embeddedness and DC to explicate business at the BOP. To answer this question effectively we select six typical enterprises in the Chinese BOP market and employed a grounded theory methodology for multi-case analysis, focusing on the following issues: (1) How does the roles of relational embeddedness play in the BOP market? (2) What are the dimensions of the DC in the BOP market and how to construct them? (3) To clarify the micro-influence mechanism of relational embeddedness on DC through the mediating role of ambidexterity learning in the context of underdeveloped regions and provide theoretical guidance and practical enlightenment for the sustainable development of the BOP market.

The contributions of this study are fourfold: First, while the conditions which bring about dynamic capabilities in business relations remain unexplored (Forkmann et al., 2018) [21], our study elaborates distinctive relational embeddedness contributing to DC. Second, the enterprise's DC is divided into three dimensions: environmental sensing, environmental adaptive, and environmental shaping capabilities. This provides a necessary foundation for the measurement of DC and the construction of conceptual dimensions based on the DC of the BOP market, as well as future DC. Third, this paper constructs a "relational embeddedness-ambidexterity learning-dynamic capability" research model, using DC as the dependent variable and ambidexterity learning as an intermediary study the influence path of relational embeddedness on DC from a knowledge perspective, extending Døving's and Gooderham's research on embeddedness to DC. Lastly, the paper is based on local cases in China. The local government is an important factor in promoting the benign interaction of network relationships. The research is different from foreign cases that emphasize the core role of NGOs or non-profit organizations in the BOP network, reflecting the characteristics of the Chinese contextual BOP market, and contributes new content.

The paper is organized as follows: After reviewing the relevant literature and addressing the major research question, we set out methods and results of multiple cases study of how six BOP-oriented enterprises developed their BOP market. Then, the following section 
contains discussion and findings. The final section contains conclusions and contributions, together with limitations, and avenues for further research.

\section{Theoretical Presupposition}

\subsection{Relational Embeddedness}

Enterprise network theory believes that enterprise can also obtain key resources through various forms of connections with external entities of the enterprise in addition to its own resources [22]. Various connections between enterprises can bring considerable relationship rent and competitive advantages to enterprises (Dyer, 1996; Dyer and Hatch, 2006; Addisu, 2020) [23-25]. Enterprise network theory can be divided into several research perspectives, among which, the embedded perspective derived from sociological research is being applied to the field of strategic management research by more and more scholars. Network embeddedness has become an important tool for studying corporate networks (Polanyi, 1944; Granovetter, 1985; Uzzi, 1997) [26-28]. Relational embeddedness is an important dimension of network embeddedness, which mainly studies the problem of binary transaction relationship between network participants, that is, the degree of mutual trust and commitment between transaction parties [28,29]. Relational embeddedness emphasizes the "assets created and leveraged through relationships" (Nahapiet and Ghoshal 1998) [30], and these assets allow relationships to become a resource for adapting or shaping the environment.

Scholars have carried out a series of studies on the impact of relational embeddedness, but there are disputes about the viewpoints and conclusions. When it comes to relational embeddedness, Granovetter [27] attached great importance to the role of weak ties and believes that weak ties can help actors access heterogeneous network nodes, so as to obtain heterogeneous information and knowledge. In contrast, Hansen [31] believes that weak ties are conducive to search and find useful, while strong ties are conducive to the transfer of complex knowledge. Levin and Cross [32] believe that strong ties can not only increase the amount of useful knowledge obtained from partners by enhancing trust but also help to transfer any kind of knowledge, while weak ties are difficult.

Some scholars believe that as far as existing research is concerned, the main factors involved in the dual relationship mechanism in the cooperative innovation network are composed of two aspects: first, the mutual trust factor between partners [33]. Trust is that one party in a relationship voluntarily produces activities with the other party and does not care whether it is at a disadvantage, so the risk taken is based on positive expectations of the other party's behavior or goals [34]. Inter-organizational trust can be regarded as a resource, which can alleviate the speculative behavior that may occur due to uncertainty and dependence in transactions. Under the restriction of the trust relationship, everyone will often reach a consensus, jointly abide by the same rules, or maintain the rules of contract changes, so that the market behavior can be continued smoothly and will not build its own interests on the interests of the trading partners (Uzzi, 1997) [28]. The establishment of trust and information sharing mechanisms provides support and guarantee for the transmission and flow of information and emotions between organizations [35]. When people trust one another, they would prefer to share proprietary and tacit information as well as information that is highly accurate, comprehensive, and timely (Kale et al., 2000, Uzzi 1996) [36,37]. In trusted relationships, people also feel safe expressing differences of opinion (Dyer and Chu 2012) [38]. The recent research found that the overall density of social links in a community promotes trustworthy and trusting behaviors with absolute strangers (Sergio Lo Iacono, 2018) [39]. Frank Charles and Susan Freeman (2021) investigate how small businesses rely on relationship-based trust (i.e., communication, social ties, and knowledge) between firms and their partners to support dynamic relationship capabilities and enhance strategic flexibility in economies in transition [40]. Second, it is the reciprocity norms between partners [41]. Both parties tend to reward each other's cooperative behavior through equal or similar efforts in alliances. Individuals in social networks participate in dense network interactions, enabling to establish reciprocity expectations among members [42]. In a social 
network full of reciprocity norms, the collective consciousness of individuals is stronger, and their behaviors are more susceptible to collective influence [43]. Individual or collective knowledge sharing behaviors are strongly influenced by reciprocity norms [44]. Reciprocity norms represent a fair knowledge exchange in which members of the community perceive each other and have a significant impact on knowledge sharing $[45,46]$. Knowledge, as one of the important resources acquired in cooperative interaction, has the closest relationship with learning. Therefore, this study draws on the literature and combines research topics to measure the level of BOP market relational embeddedness from the two dimensions of mutual trust and reciprocity norms.

\subsection{Dynamic Capability}

Teece first proposed the concept of DC, and afterward, this research topic has attracted wide attention from domestic and foreign scholars [47,48]. Teece, Pisano, and Shuen (1997) defined DC as the firm's ability to integrate, build, and reconfigure internal and external competencies to address rapidly changing environments [48]. Later, scholars expanded the concept of DC based on Teece's research and formed two different views. Some scholars believe that DC is a behavioral orientation that guides companies to update, integrate, and reshape core capabilities. For instance, Zollo and Winter (2002) believed that DC is a learnable and relatively stable mode of action for an enterprise. Through this model, an enterprise can systematically improve its operation and management to increase its efficiency [49]. Wang and Ahmed (2007) also started from a behavior-oriented perspective, and believe that DC is the behavioral orientation of enterprises to continuously integrate, reconfigure, update, and rebuild their resources and capabilities [50].This stream attempts to clarify the component factors of dynamic capability such as adaptive, absorptive, and innovative capability (Wang and Ahmed, 2007) [50]; integration capability, learning capability, and reconstruction capability (Wu, 2010) [51]; reconfiguration, leveraging, learning, and creative integration (Bowman and Ambrosini, 2003) [52]; and exploitative dynamic capabilities and explorative dynamic capabilities (Monferrer, 2015; Dixon, 2014; Liu, Yu and $\mathrm{Wu}, 2019$ ) [53-55]. Other scholars believe that DC is specific identifiable behavioral processes and capabilities. For instance, Eisenhardt and Martin (2000) believe that DC are identifiable conventions and processes, which are embodied in the process of acquiring, integrating, reconfiguring, and stripping resources to match or create market changes. They are the capabilities that formed and developed on the basis of a series of dynamic combinations of resources [56]. This stream attempts to disaggregate the component factors of dynamic capability such as and product development, alliance, and strategic decision-making capability (Eisenhardt and Martin, 2000) [56]; heterogeneous human capital, internal development routine and alliance capability across organizational boundaries (Døving and Gooderham, 2008) [20]; architectural innovation (Galunic and Eisenhardt, 2001) [57]; or focus on dynamic capabilities in specific functions, such as marketing (Bruni and Verona, 2010) [58], research, and development (Danneels, 2008) [59].

It can be seen from the above definition and classification that whether DC are behavior-oriented or specific capabilities, they all demonstrate the determination of enterprises to respond to environmental changes by integrating internal and external resources and capabilities $[60,61]$. Therefore, this study adopts the definition of Teece and believes that dynamic capability is an advanced capability. When an organization adapts to an externally changing environment through integration, construction, and reconfiguration of internal resources and capabilities, the enterprise has a dynamic capability. Teece (2007) divides DC into environmental sensing, environmental adaptative, and environmental shaping capability from an environmental perspective [62]. The dynamic capability of an enterprise is essentially an ability to adapt to the external environment and emphasizes the active role of the enterprise [54]. The enterprise is not just passively adapting to the environment, but can also change or even reshape the environment through corresponding activities [63]. 
Environmental sensing capability means that companies can explore and obtain innovation opportunities from the external environment and help companies seize market opportunities and the commanding heights of innovation. They not only adapt to business ecosystems, but also shape them in terms of innovation and collaboration with other enterprises, entities, and institutions after its deployment through discovery, trial and error, and fine-tuning [64]. Adaptive capability refers to the ability of an enterprise to identify and use market opportunities based on changes in the external market environment (Chakravarthy, 1982; Miles and Snow, 1978) [65,66], which focuses on adaptability to the external environment and the balance between strategy and environment [51], and expresses the internal flexibility of corporate resources and the flexibility of using these resources through corporate strategic flexibility (Sanchez, 1995) [67]. The evolution of organizational flexibility is accompanied by the development of adaptability. The ability to adapt to changes in the external environment and the ability to integrate internal resources to meet external needs are critical to the evolution and survival of enterprises in the industry [63]. Adaptive capability is a continuous variable. A low level of adaptability means that an enterprise rarely pays attention to the internals, just identifies and employs part of the market opportunities, and faces the risk of failure at any time due to lack of attention to changes in the external environment, while a high level of adaptability means firms focus on external changes, can identify and tap more market opportunities, and can quickly adapt to changes in the external environment [66]. Shaping capability is the ability to take advantage of innovation opportunities and transform them into innovation results consisting of a series of routines and processes (Cohen, 2000) [68], which shape the ecosystem it occupies, develop new products and processes, and design and implement viable business models. Alternatively, firms can also generate or cultivate a local supply chain by, for example, training and educating raw material producers, financial institutions, and/or local labor (Ramachandran et al., 2011) [19], which would shape the context and create a more suitable environment in turn.

In recent years, scholars of the DC school have gradually begun to highlight that knowledge is the most strategically valuable core resource. DC exists in a series of management processes such as the acquisition, absorption, creation, integration, and reconstruction of knowledge [56,69]. The current research on DC mainly focuses on the process of DC, the impact of DC on performance and competitive advantage [70,71], and certain research progress has been made. However, these studies merely answer why DC is important, but fail to fully explain the DC and how to build DC. Zollo and Winter (2002) posed the question: where do dynamic capabilities come from and how are their underpinning routines generated [49] ? Eriksson (2004) calls for a more holistic understanding of dynamic capabilities [72]. There are few studies on the antecedent variables of DC, and they are mainly limited to the impact of organizational learning and organizational resources on DC $[73,74]$. In the research of antecedent variables, some scholars have proposed that the environment affects DC [75]. Existing research on the environment, especially the impact on DC under the $\mathrm{BOP}$ environment, is still rarely involved. This research puts forward the relationship between relational embeddedness and DC in the context of BOP cooperation networks, which will help us understand how to build and improve DC in the future.

\subsection{Ambidexterity Learning}

According to March's research, the organization pursues both exploitative learning and exploratory learning [76,77]. Exploitative learning refers to the learning behavior characterized by refining efficiency, choice, and execution, and is to reduce variation, stability. Efficiency orientation emphasizes slow changes and reforms in existing products or knowledge fields [78], and efficiency, refinement, and implementation [79]. Exploratory learning is a form of organizational learning closely related to search, change, experimentation, risktaking, flexibility, discovery, innovation, etc., which means grasping new technologies and new business opportunities [77,80], including acquiring new knowledge and discovering new customer needs, developing new markets, applying new knowledge, adopting new 
technologies, etc. Ambidexterity has also been often highlighted as a mechanism to attain sustainability [81,82].

Resources are the foundation of capabilities, and building dynamic capabilities requires valuable, scarce, inimitable, and irreplaceable resources. Man (2001) studied the relationship between knowledge, learning, and DC. He believes that learning capability not only improves the DC of the enterprise but also accumulates a strong knowledge base through learning, forming a knowledge chain that competitors cannot imitate. Eisenhardt and Martin (2000) believes that the learning mechanism not only guides the evolution of dynamic capability but also forms the basis of path dependence [56]. Ambidexterity learning is an important way for enterprises to build DC and the key lies in integrating new and existing resources (including information and knowledge, etc.). The resource characteristics of the BOP market, which is different from that of the TOP market, enable companies to strengthen internal learning and knowledge accumulation while also going beyond organizational boundaries to obtain native resources. For the formation process of dynamic capabilities, exploitative learning and exploratory learning activities are essential $[56,77,83]$. Therefore, this research assumes that ambidexterity learning has a positive effect on DC.

In summary, BOP offers a suitable context in which to build DC with regard to the adaptation to and shaping of the context because firms are advised to adapt to their context and build on local conditions (Hart and London, 2005) [9]. Simultaneously, firm activities are also expected to radically change the context in which they operate by introducing new products and services (Prahalad and Hammond, 2002) [84]. As a counterpoint to this, in later literature on the BOP, it has been argued that firms must become socially embedded (Hart and London, 2005) [9] and use ambidexterity learning in order to succeed at the BOP. In order to study how Chinese local companies, integrate and utilize network resources and promote sustainable development in the BOP market, this paper focuses on the basic problem of how relational embeddedness affects DC, and deeply analyzes the impact of network relationships on the construction of DC, trying to shed light on the black box of this mechanism. Through exploratory case studies of six companies, this paper deeply explores the relationship between the embeddedness of the company in the BOP cooperation network and its own DC. This study will introduce ambidexterity learning as an intermediary variable into the mechanism by which relational embeddedness affects the DC of enterprises and examine whether social embeddedness affects the DC of enterprises by acting on ambidexterity learning (as shown in Figure 1).

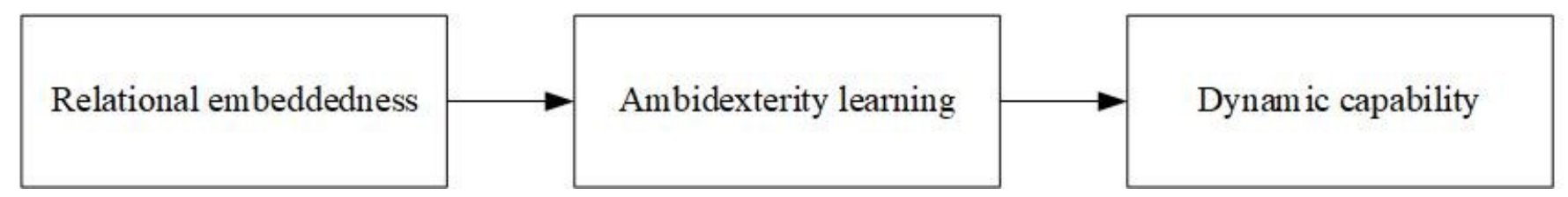

Figure 1. Theoretical presupposition of the influence mechanism of relational embeddedness on dynamic capability. (Source: Own elaboration).

\section{Research Methodology}

Given the limited relevant theories and empirical evidence in the literature, we adopt an inductive theory building approach (Eisenhardt, 1989) [85]. To identify how relational embeddedness affects dynamic capability, an exploratory study was developed through multiple case studies, which, for Eisenhardt (1989) [85] were set up in the most adequate way to understand how and why certain phenomena occur. Eisenhardt (1989) [85] and Hartley (2004) [86] state that the aim of the case study was to provide an analysis of the context and processes that illuminate the theoretical issues being studied. The appropriateness of adopting the case study approach depends on the nature of the research, which is derived from the research problem and the objective (Ghauri and Grønhaug, 2005) [87]. As the aim of this study is to obtain a deeper understanding of relational embeddedness 
and DC through the mediating role of ambidexterity learning, then the multi-case study research methodology would be valuable in providing explanations. For Flick (2009) [88], a case study may describe the complexity of a given phenomenon and analyze the interaction between variables experienced by the social groups investigated.

The multiple-case design has increased in popularity among researchers in recent years (Yin, 2009) [89] and is generally regarded as a more persuasive and elaborate case design than the single-case design (Herriott and Firestone, 1983) [90]. Figure 2 shows the multiple-case design steps by Yin. As the first step of this study, a theory was developed. The cases were selected, and the data was collected in the following step. Reports for each case study were then created while performing the case studies. This study aims at deducting a comprehensive conclusion after comparing all the cases. The theory was constantly modified throughout this process. The policy implementation measures were derived before the comprehensive case study was reported. Lastly, the comprehensive report of the case study was created.

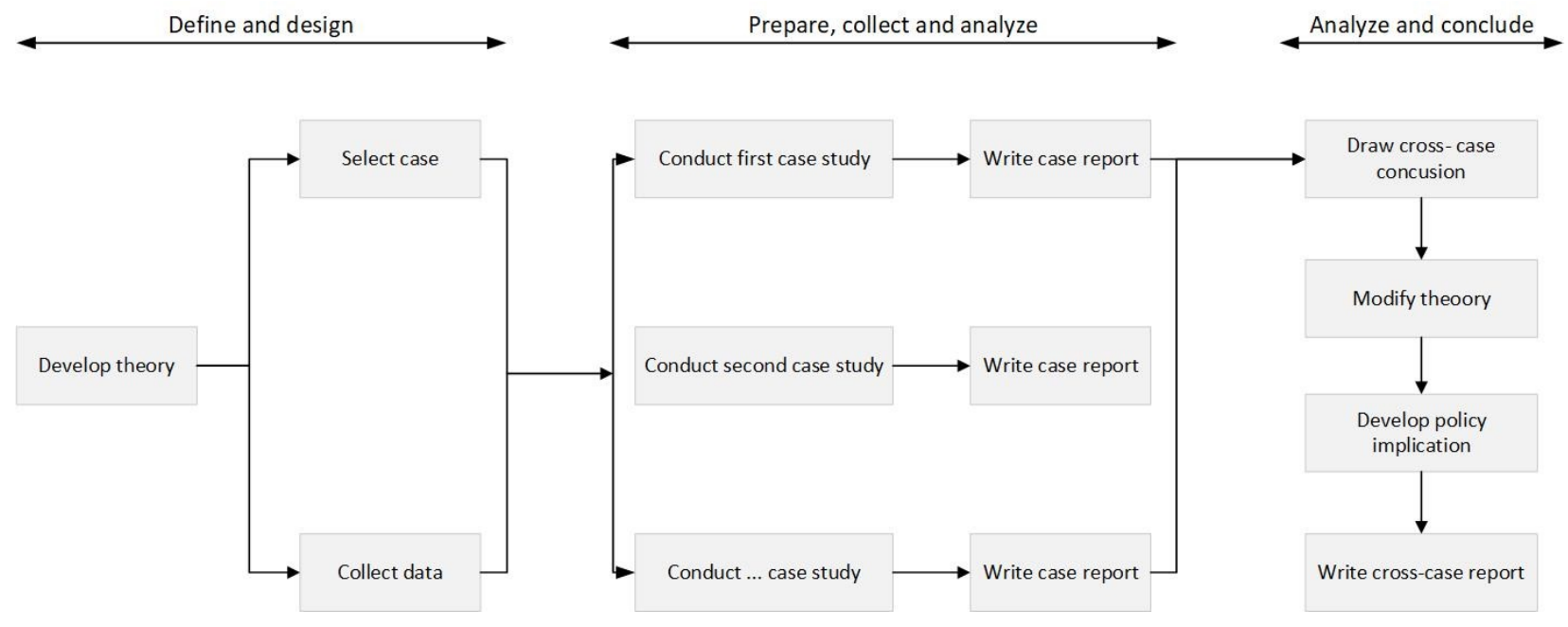

Figure 2. Case study method. (Source: Yin).

\subsection{Case Selection}

For the performance of this study, the following two main criteria are considered when choosing a case:

First, we considered information-rich events purposely (Hillebrand, Kok and Biemans, 2001; Patton, 2015) [91,92] in sample firms, so as to obtain events that are critical to the purpose of the research, which are particularly suitable to untangle the black box of relational embeddedness on dynamic capability. We began to identify the ideal BOP enterprises. Particularly, our target enterprises are those that have survived and grown in the BOP market, so as to increase the possibility that these enterprises rely on relationships to develop dynamic capability (Helfat et al., 2007; Smart, Bessant, and Gupta, 2007) [93,94].

Second, to acquire a more comprehensive understanding of the selected enterprises involved, we made sure that our samples included various enterprise types and as many upstream and downstream linkages in the supply as possible. Such as, (1) balance between different BOP business models: 2 companies in the sample see BOP people as producers and sellers, and 4 companies see BOP people as producers; (2) balance between types of companies: covers in nature listed companies, state-owned enterprises, private enterprises, etc., and include large, medium, and small scales; and (3) thematic comparisons can be made. We mainly follow the principle of literal replication recommended by Yin (2002b) [95] and select representative cases that are as similar as possible in each BOP business.

Applying these standards to candidates, we generated a list of 30 candidates, of which 10 BOP-oriented enterprises were contacted. In terms of the number of cases, Eisenhardt (1989) believes that 4 to 8 in the multi-case study is the ideal number of original cases 
used in the induction [85], and Yin (2002a) believes that number is 6 to 10 [95]. Therefore, considering the basic requirements of theoretical construction and the marginal utility of increased cases, this study selected 6 cases located in the Qinba Mountains as the final research sample (see Table 1), one of the 14 contiguous and extremely poor areas in China.

Table 1. The sample firms outline.

\begin{tabular}{cccc}
\hline Enterprise & Main Business & Organizational Form & Established \\
\hline Y & Pig breeding and processing & Large private enterprise & 2007 \\
Z & Tea planting, production, and marketing & Large state-owned enterprise & 1985 \\
P & Biopharmaceutical & Medium-sized listed companies & 1997 \\
B & Biopharmaceutical & Medium-sized private enterprise & 2005 \\
S & Agricultural product distribution & Small private enterprise & 2009 \\
M & Agricultural product distribution & Small private enterprise & 2018 \\
\hline
\end{tabular}

(Source: Own elaboration).

\subsection{Date Collection}

All the data in this research is new. We used documentary and archival records to gather secondary data and conducted interviews and focus groups with business experts and industrial managers who work at companies used as cases in this research. According to the principle of the "evidence triangle" of collecting data in case studies Yin (2009), the research team combined the resources it possessed and used as many research methods as possible to obtain information and materials from various data sources around the research questions. To ensure reliability and validity, data were triangulated from multiple sources (Yin, 1994) [96], mainly collected from corporate background, company profile, operation and development, and other aspects. The types of data collected include: (1) collect primary data mainly by means of field observation and semi-structured interviews. The interviewees included senior corporate managers, BOP business department heads, technical personnel and as many external stakeholders as possible. The survey was from June 2019 to March 2021.

Stage I, we focused on fully understanding the process and development of each firm, including the critical events with the participants were involved. In doing so, we employed the critical event technique (Flanagan, 1954) [97], which requires each respondent to identify, narrate, and highlight relationship dynamics in which they have been involved and that bore clear relevance to dynamic capability (environmental sensing, adaptive, and shaping capability). Furthermore, interviewees were asked to express the background, partners, process, and results of the events, etc. with the purpose of identifying and examining any underlying relational embeddedness aspects.

Stage II of interview was concentrated to validate the preliminary findings from the stage I data and further clarify the preliminary assumptions from the cross-case analysis, especially the mechanism of relational embeddedness on dynamic capability under the mediation of ambidexterity learning. In doing so, we conducted an additional interview with senior executives. Before the survey, interviewees were presented with a series of key events as well as involved partners. For each activity, the interviewees are showed the preliminary results, which are aspects of dynamic capabilities identified based on the results of the stage I analysis. Regarding the different roles of relational embeddedness played, we asked some "why" questions, such as "Why specifically did you cooperate with A in your innovation activities over supplier B?" or "Why are BOP groups willing to participate in this planting or breeding mode?".

In addition to primary data, the collection of secondary data includes: (2) company information collected from the government's and company's websites, microblog, and WeChat; (3) published magazines and related information; and (4) published literature, media materials, and related books about advance research. The data collection of this case study mainly comes from these 4 different channels. It follows the "evidence triangle" rule, which forms a triangular verification between data from different sources, thus improving 
the reliability and validity of this study, and making this study conclusion convincing and accurate.

\subsection{Date Analysis}

This paper chooses grounded theory to code and analyzes data, and mines the category of data through open coding, axial coding, and selective coding, and identifies the nature of the category and the relationship among the categories (Glaser, 1992; Strauss and Corbin, 1990) $[98,99]$, thus building the theory from the bottom up. After the data is collected and sorted out, we use NVivo 11 to assist the code analysis under the conditionbehavior/interaction-result logical relationship to abstract new concepts and opinions from the data, and carry out logical demonstrations under the idea of verification or falsification, and discover new interactions and organizations mode [100].

Step I: open coding is the process of decomposing, refining, conceptualizing, and categorizing sentences and snippets from the interview. We recorded and transcribed interviews data conducted in stages I and II, and read each transcript word by word and line by line (Strauss and Corbin, 1990) [99]. Then, we opened up the text by breaking it down into distinct units of meaning (Goulding, 2002) [101] to uncover the thoughts and meanings therein (Strauss and Corbin, 1998) [102]. In doing so, we assigned specific analytic dimensions to each paragraph, which displays relational embeddedness, ambidexterity learning, and three clusters (sensing, adaptative, and shaping) of dynamic capabilities. To do so, mutual trust, reciprocity norms, acquisition/utilization of new/existing knowledge, perceive risks and opportunities, improvement/innovation were also allotted to those paragraphs that revealed or indicated these conditions. Some paragraphs were given more than one code.

Step II: axis coding is to analyze the potential relationships between sub-categories, gradually merge, refine, and integrate the main categories. Drawing on the views of Strauss and Corbin (1990) [99], this paper adopts the coding paradigm of conditional action/interaction result to find the connections between several initial categories. We sought both to connect the open coding results to determine the nature and dimension of related categories of some established concepts, such as relational embeddedness, ambidexterity learning and to generate new dynamic capability types.

Step III: the selection coding, where the core category or theoretical dimension of the dominant role is summarized in the main category, and it is systematically related to other categories, so as to construct a systematic theoretical framework. During the coding process, categories with similarities and differences are constantly compared, analyzed, and revised to improve theoretical accuracy and realize theoretical innovation [103]. Due to the complexity of the process (refer to Ausrød et al. [64]) this paper shows only the coding process and results as shown in Tables 2-5.

Table 2. Coding results of the sample firms.

\begin{tabular}{|c|c|c|c|}
\hline First Order Open Coding & Second Order Open Coding & Axial Coding & Selective Coding \\
\hline $\begin{array}{l}\text { Leading enterprises drive, keep promises, } \\
\text { sincerely and friendly cooperation }\end{array}$ & Mutual trust & \multirow{2}{*}{$\begin{array}{c}\text { Relational } \\
\text { embeddedness }\end{array}$} & \multirow[t]{2}{*}{ Social embeddedness } \\
\hline Resource sharing, information exchange & Reciprocity norms & & \\
\hline Planting experience and know-how & $\begin{array}{l}\text { Acquisition of existing } \\
\text { knowledge }\end{array}$ & \multirow{2}{*}{ Exploitative learning } & \multirow{4}{*}{$\begin{array}{l}\text { Ambidexterity } \\
\text { learning }\end{array}$} \\
\hline $\begin{array}{l}\text { Technology improvement, channel } \\
\text { integration }\end{array}$ & $\begin{array}{l}\text { Utilization of existing } \\
\text { knowledge }\end{array}$ & & \\
\hline $\begin{array}{l}\text { New knowledge, new information, new } \\
\text { resources }\end{array}$ & $\begin{array}{l}\text { Acquisition of new } \\
\text { knowledge }\end{array}$ & \multirow{2}{*}{ Exploratory learning } & \\
\hline $\begin{array}{l}\text { New technologies, new channels, new } \\
\text { products }\end{array}$ & Utilization of new knowledge & & \\
\hline
\end{tabular}


Table 2. Cont.

\begin{tabular}{cccc}
\hline First Order Open Coding & Second Order Open Coding & Axial Coding & Selective Coding \\
\hline $\begin{array}{c}\text { Business risks, research trends, changes in } \\
\text { demand }\end{array}$ & $\begin{array}{c}\text { Perceive risks and } \\
\text { opportunities }\end{array}$ & Sensing capability & Dynamic capability \\
\cline { 1 - 2 } $\begin{array}{c}\text { Integration of internal and external resources } \\
\text { and processes }\end{array}$ & Improvement and integration & Adaptive capability \\
\cline { 1 - 2 } $\begin{array}{c}\text { Supply chain construction, business model } \\
\text { innovation }\end{array}$ & Refactoring and Innovation & Shaping capability \\
\hline
\end{tabular}

(Source: Own elaboration).

Table 3. Relational embeddedness level of the sample firms.

\begin{tabular}{ccc}
\hline Mutual Trust & Reciprocity Norms \\
\hline $\begin{array}{c}\text { Cooperating parties keep their promises, } \\
\text { and they can communicate and resolve } \\
\text { together as soon as possible even if there } \\
\text { are differences or potential problems. }\end{array}$ & $\begin{array}{c}\text { The company establishes an interest linkage mechanism for "companies, } \\
\text { farmers, and poor households", that poor households the poverty alleviation } \\
\text { fund to buy shares, and will receive dividends at the end of the year; the } \\
\text { company provides piglets, technology, feed, etc., and Sign the purchase } \\
\text { agreement. Government coordinated to solve various problems on the spot } \\
\text { and held monthly special meetings to supervise and discuss the progress of } \\
\text { the project to ensure the completion of the project. }\end{array}$ \\
$\begin{array}{c}\text { Signed a long-term cooperation } \\
\text { agreement to trust each other and keep } \\
\text { promises }\end{array}$ & $\begin{array}{c}\text { Company Z has established an order-based production and sales cooperation } \\
\text { relationship with backbone tea companies to increase the value of local tea's } \\
\text { brand and increase the purchase price of fresh leaves for farmers. While } \\
\text { farmers increase their enthusiasm for picking fresh leaves and quality } \\
\text { standards and guarantee high-quality raw materials for tea production. }\end{array}$ \\
\hline
\end{tabular}

The company has signed an order for planting Chinese medicinal materials with a professional cooperative and

$\mathrm{P} \quad$ believes in the intention of friendly and sincere cooperation between the other partners, and basically keeps their promises.

The company signs a medicinal planting assistance agreement with poor

B households, and both parties trust each other to plant and purchase according to the contract.
P Company fed back the mountainous area, setting Charity Poverty Alleviation Fund, improv education and transportation. Thanks to the financial support of policy and funding, more than a dozen topics of the company have been effectively advanced and the company successfully completed the listing.
The government has increased its policy support and promote enterprises to achieve independent innovation, so the company established a provenance cultivation base for Chinese medicinal materials and standardized order planting. It not only guarantees the quality and demand of medicinal materials, but also helps farmers increase income and get rid of poverty.

The company has consistently adhered to honest and trustworthy operations, upholding corporate social responsibility, and undertaking public welfare, winning the trust of the people, and the company grows. For example, donate money and materials during the epidemic to help poor college students and out-of-school children in pairs, and help the disabled find employment.

The company sign purchase and sales orders for agricultural and sideline products, establish online poverty alleviation, carry out industrial technical training, and provide jobs, which has increased the income of the poor and the sound development of enterprises through the positive interaction between poverty alleviation. 
Table 4. Exploitative/Exploratory learning level of the sample firms.

\begin{tabular}{|c|c|c|c|c|}
\hline & \multicolumn{2}{|c|}{ Exploitative Learning } & \multicolumn{2}{|c|}{ Exploratory Learning } \\
\hline & $\begin{array}{c}\text { Acquisition of } \\
\text { Existing Knowledge }\end{array}$ & $\begin{array}{c}\text { Utilization of Existing } \\
\text { Knowledge }\end{array}$ & $\begin{array}{c}\text { Acquisition of New } \\
\text { Knowledge }\end{array}$ & $\begin{array}{l}\text { Utilization of New } \\
\text { Knowledge }\end{array}$ \\
\hline Y & $\begin{array}{l}\text { The enterprise obtains } \\
\text { the local large-scale } \\
\text { supermarket chain } \\
\text { counter sales network. }\end{array}$ & $\begin{array}{l}\text { The enterprise relies on the } \\
\text { existing ecological } \\
\text { selenium-enriched pork } \\
\text { supermarket chain counter sales } \\
\text { network to optimize and } \\
\text { upgrade sales channels. }\end{array}$ & $\begin{array}{l}\text { Based on the unique local } \\
\text { selenium-rich resources, it } \\
\text { cooperated with universities to } \\
\text { build three professional } \\
\text { laboratories for swine disease } \\
\text { detection, selenium-enriched } \\
\text { feed analysis, and research and } \\
\text { development, and established } \\
\text { Yangchen Research Institute, a } \\
\text { full-time pig breeding and } \\
\text { selenium-enriched pork and } \\
\text { feed. }\end{array}$ & $\begin{array}{l}\text { R\&D and production of } \\
\text { "Kang Se Valley" brand } \\
\text { ecological } \\
\text { selenium-enriched pork } \\
\text { and “Chaotianhe" brand } \\
\text { pig feed; innovative risk } \\
\text { management model, in the } \\
\text { company to carry out } \\
\text { DCE's pig breeding feed } \\
\text { (corn, soybean meal) cost } \\
\text { price insurance pilot } \\
\text { project }\end{array}$ \\
\hline Z & $\begin{array}{l}\text { The enterprise } \\
\text { understands the } \\
\text { varieties and } \\
\text { distribution of local } \\
\text { high-quality tea } \\
\text { resources and improves } \\
\text { tea picking standards. }\end{array}$ & $\begin{array}{l}\text { The enterprise upgrades the } \\
\text { entire industrial chain } \\
\text { management and control, and } \\
\text { the "company + supplier + } \\
\text { farmer" operating model, } \\
\text { continuously improves the } \\
\text { quality of fresh tea picking, and } \\
\text { provides natural, green, healthy, } \\
\text { and safe high-quality raw } \\
\text { materials for tea production. }\end{array}$ & $\begin{array}{l}\text { The company selected Ziyang } \\
\text { Maojian among many Ziyang tea } \\
\text { products to focus on, and } \\
\text { developed novel tea products } \\
\text { based on the original formula } \\
\text { and improved quality. }\end{array}$ & $\begin{array}{l}\text { Combining China Tea's } \\
\text { advanced tea-making } \\
\text { technology, jointly } \\
\text { developed Ziyang } \\
\text { Se-enriched Ecological Tea, } \\
\text { and launched a new } \\
\text { product “China Tea Brand } \\
\text { Ziyang Se-enriched } \\
\text { Maojian". }\end{array}$ \\
\hline $\mathrm{P}$ & $\begin{array}{l}\text { The enterprise goes } \\
\text { deep into the local area } \\
\text { to obtain current } \\
\text { market information of } \\
\text { the medicine source of } \\
\text { the traditional Chinese } \\
\text { medicine industry, } \\
\text { understands the texture } \\
\text { of local Chinese herbal } \\
\text { medicines, and strictly } \\
\text { control the cultivation } \\
\text { of medicinal materials. }\end{array}$ & $\begin{array}{l}\text { The enterprise optimizes } \\
\text { production factors, makes full } \\
\text { use of the region's rich resources } \\
\text { of Chinese medicinal material, } \\
\text { integrates the enterprise } \\
\text { medicine source market, } \\
\text { cooperates with local Chinese } \\
\text { herbal medicine planting } \\
\text { cooperatives, and adjusts } \\
\text { planting varieties as needed. }\end{array}$ & $\begin{array}{l}\text { Based on the company's efforts } \\
\text { to increase research and } \\
\text { development of new drugs, } \\
\text { strengthen research and } \\
\text { development cooperation with } \\
\text { universities and scientific } \\
\text { research institutions, continue to } \\
\text { increase investment in new } \\
\text { processes, new technologies, and } \\
\text { new product development and } \\
\text { innovation, and make efforts in } \\
\text { product development and } \\
\text { technological innovation. }\end{array}$ & $\begin{array}{l}\text { Actively carry out the } \\
\text { research and development } \\
\text { of new drugs, generic } \\
\text { drugs, and big health } \\
\text { products. Focusing on the } \\
\text { creation of skeletal and } \\
\text { muscle products, } \\
\text { hepatobiliary products, } \\
\text { cardiovascular and } \\
\text { cerebrovascular products, } \\
\text { pediatric products and } \\
\text { gynecological products, the } \\
\text { product line continues to } \\
\text { be enriched. }\end{array}$ \\
\hline
\end{tabular}

The enterprise continues to promote standardized planting techniques of various Chinese medicinal materials in counties and districts, establish

The enterprise obtains experience in base

B construction and standardized planting techniques. standardized planting bases, and continuously optimize

production conditions relying on policy support. The scientific and standardized planting process guarantees the purity of the source of medicinal materials, and the quality and curative effect of medicines are strongly guaranteed.
The company seized the opportunity of being included in the pilot production enterprises of traditional Chinese medicine formula particles, cooperated with well-known scientific research institutions and experts at home and abroad, established academician workstations, established its own scientific research platform, and conducted extensive exchanges and cooperation with relevant scientific research and technical personnel.
Speed up the development and production of Chinese medicine formula granules. 
Table 4. Cont.

\begin{tabular}{|c|c|c|c|c|}
\hline & \multicolumn{2}{|c|}{ Exploitative Learning } & \multicolumn{2}{|c|}{ Exploratory Learning } \\
\hline & $\begin{array}{c}\text { Acquisition of } \\
\text { Existing Knowledge }\end{array}$ & $\begin{array}{c}\text { Utilization of Existing } \\
\text { Knowledge }\end{array}$ & $\begin{array}{c}\text { Acquisition of New } \\
\text { Knowledge }\end{array}$ & Utilization of New Knowledge \\
\hline S & $\begin{array}{l}\text { The enterprise uses } \\
\text { local logistics network, } \\
\text { acquires logistics } \\
\text { management } \\
\text { experience, integrates } \\
\text { local logistics } \\
\text { enterprises. }\end{array}$ & $\begin{array}{l}\text { Integrate local logistics } \\
\text { companies. The enterprise has } \\
\text { successively established a } \\
\text { county-level online goods } \\
\text { supply center, set up agricultural } \\
\text { product display areas in town } \\
\text { and village service outlets, and } \\
\text { guided village-level service } \\
\text { outlets to form professional } \\
\text { cooperatives, building a } \\
\text { comprehensive e-commerce } \\
\text { logistics base of } 30,000 \text { square } \\
\text { meters, integrating warehousing, } \\
\text { transportation, distribution, } \\
\text { information exchange, business } \\
\text { circulation and trading. }\end{array}$ & $\begin{array}{l}\text { Get timely information on } \\
\text { high-quality agricultural } \\
\text { products, understand } \\
\text { market trends, and } \\
\text { innovate sales models. }\end{array}$ & $\begin{array}{l}\text { In response to the new market } \\
\text { demand, the "Four Unifications" } \\
\text { marketing model has been } \\
\text { formulated for unified standards } \\
\text { for special agricultural products, } \\
\text { unified processing and } \\
\text { packaging, unified brand } \\
\text { operations, and unified external } \\
\text { sales. }\end{array}$ \\
\hline M & $\begin{array}{l}\text { Responding to the call } \\
\text { of the policy, the } \\
\text { enterprise helps the } \\
\text { industry to alleviate } \\
\text { poverty, and build a } \\
\text { brand with local } \\
\text { characteristics. }\end{array}$ & $\begin{array}{l}\text { Embedded in the industrial } \\
\text { chain, the enterprise integrates } \\
\text { product base, optimize } \\
\text { packaging, improves quality } \\
\text { brand, and optimizes logistics } \\
\text { and distribution. }\end{array}$ & $\begin{array}{l}\text { Based on the local area, } \\
\text { understand the } \\
\text { distribution of local } \\
\text { agricultural special } \\
\text { product resources and } \\
\text { product sales difficulties, } \\
\text { tap new market demand, } \\
\text { and identify the potential } \\
\text { of online channels. }\end{array}$ & $\begin{array}{l}\text { Innovative business model. } \\
\text { Based on the establishment of } \\
\text { offline sales counters for poverty } \\
\text { alleviation products, it adopted } \\
\text { the sales model of "e-commerce+ } \\
\text { cooperatives + farmers" and } \\
\text { successfully entered the China } \\
\text { Social Poverty Alleviation } \\
\text { Online Marketing } 832 \text { platform, } \\
\text { expanding new sales channels. }\end{array}$ \\
\hline
\end{tabular}

(Source: Own elaboration).

Table 5. Dynamic capability level of the sample firms.

\section{Environmental Sensing Environmental Adaptive Capability \\ Capability \\ Environmental Shaping Capability}

The company has a relatively good understanding of the development status and

$\mathrm{Y}$ trends of the industry and can

be keenly aware of potential market opportunities and risks.
In order to solve the problem of insufficient liquidity of farmers, the forms of "company + farmers" and "Alternative feeding" are adopted to support the villagers to raise pigs. The company provides farmers with pig seedlings and

technology and solve the sales and other problems.
Under the call of the government and led by the group, the company reached a cooperative model of "Pig Industry Alliance", adopted the model of

"pig-methane-fertilizer-vegetable" combined planting and breeding, and carried out first-class planning,

design and operation management, which formed the

benign interaction of capital, technology, management, materials, sales and other links. In addition, the

company is striving to become a low-carbon, green, and environmentally friendly sustainable modern agricultural and animal husbandry enterprise.

The company dispatched an expert technical team to Ziyang to plan and guide, improve the tea planting specifications, optimize the tea production process, realize the whole process monitoring from the tea garden to the cup, and ensure that the product quality is controlled from the source.
Through brand co-building, product co-creation, channel sharing, standard output, technical assistance, chain docking, and other precise development strategies, it will explore and develop differentiated, personalized, and characteristic new tea products that meet consumer recognition. 
Table 5. Cont.

Environmental Sensing Capability
Environmental Adaptive Capability

By optimizing production factors, adapting measures to local

Have a certain understanding of the latest research results in related fields and have a clear understanding of the company's business risks and strategic directions. conditions, rational planning, and large-scale operations, the company has promoted product branding and large-scale planting, and has also driven farmers to get out of poverty.

\section{Environmental Shaping Capability}

P Company seized the opportunity of pharmaceutical logistics development and built a pharmaceutical logistics and R\&D center in Xi'an Chanba Ecological Zone to build a smart logistics platform integrating pharmaceutical sales and distribution, modern logistics, pharmaceutical information consulting, medicinal materials storage and processing, and product development to build a modern Chinese herbal medicine circulation system.

The company standardizes the planting process to ensure the purity of the source of medicinal materials, and the quality and efficacy of the medicines are strongly guaranteed.
The company innovates scientific research, Gulan Cystat, new anti-tumor drugs, two projects.

\section{Combining with changes in the} market environment and based on the local area, the company gave full play to the leading role of county e-commerce services in rural designated facilities enterprises and responded to the " 100 enterprises to help hundreds of villages" social poverty alleviation public welfare action. Exploit the demand for local offline department store products to enter villages and households, and online agricultural and sideline products to enter cities, and innovate business models.
Under the policy guidance, the company actively responds to the government's call to tap and meet the needs of producers and customers.
The company focuses on online and offline sales services, enters the village, finds out the foundation, establishes a good account, opens channels, displays and promotes products, and clears the "last mile" of consumer terminals.
The innovation model has promoted the innovation of Ziyang's agricultural and sideline products production, processing, logistics, catering services and other related industries, extended the industrial chain, and established local poverty alleviation industrial projects.

(Source: Own elaboration).

\section{Case Analysis}

In the following, the description and analysis of the relational embeddedness, ambidexterity learning, and DC of each case company are carried out to obtain structured and coded data information for further in-depth analysis of the relationship between variables. Through continuous comparisons, we explore the correlation and causality among variables and furthermore put forward research propositions.

\subsection{Relational Embeddedness}

Drawing lessons from the research of Uzzi [28], Das T K [33], and Johanson J [41], after the analysis of the relevant cases, this study identifies two dimensions of mutual trust at the formal level and reciprocity norms at the implementation level to characterize the relational embeddedness of enterprises in the BOP cooperation network. The result is consistent with the work of Uzzi, Das, and Johanson. Mutual trust is mainly manifested in that related companies, local governments, and BOP groups keep their promises and cooperate for a win-win situation. They share information more actively and voluntarily. 
Cooperating parties keep their promises and can communicate and resolve them together as soon as possible even if there are debates or potential problems. For instance, company $\mathrm{P}$ has signed an order for planting Chinese medicinal materials, which is to provide farmers with seedlings and nursery expenses, pay planting wages every day, and purchase them by order. Company B signed a medicinal planting assistance agreement with farmers, planted and purchased in accordance with the contract, and provided timely guidance on problems in the process. Reciprocity norms are mainly reflected in the fact that the company often goes deep into the $\mathrm{BOP}$ cooperation network to carry out reciprocal activities and jointly solve problems with the government. For instance, company $\mathrm{Y}$ establishes an interest linkage mechanism of "company, breeder, and poor households", and poor households use poverty alleviation funds to buy shares and participate in dividends at the end of the year. In the pig breeding project, the government coordinated to solve various problems on the spot and held monthly special meetings to ensure the completion of the project. In addition, relevant companies have established skills training mechanisms for local farmers, devoted themselves to public welfare undertakings (Companies $\mathrm{Y}, \mathrm{Z}$, and $\mathrm{P}$ ), established charitable poverty alleviation funds, helped build or renovate rural roads, and promoted education and education (Companies $\mathrm{Y}, \mathrm{S}$, and $\mathrm{P}$ ). After data sorting, the paper obtained mutual trust and reciprocity norms of sample firms. The results are shown in Table 3.

\subsection{Ambidexterity Learning}

Research on organizational learning usually uses exploitative learning and exploratory learning proposed by March (1991) [76]. In the course of business development, companies must not only deepen their existing business through exploitative learning to ensure profits but also explore new technologies, emerging markets, and new business areas through exploratory learning to ensure future benefits. It can be found that there is a certain correspondence between knowledge types and organizational learning. Provided that the knowledge acquired by the enterprise is unfamiliar, future, or foreign knowledge, it is exploratory learning. Provided that it is already understood, existing, local, the knowledge that is used is exploitative learning (Gupta et al., 2006) [104]. Exploitation occurs when firms rely on existing competencies or operational capabilities to sell to existing customers. As the two learning methods mainly occur in the links of the knowledge acquisition and knowledge application, this study measures the ambidexterity learning behavior of enterprises through the acquisition and utilization of new and existing knowledge.

After analyzing six cases one by one, we found two types of learning: exploitative learning and exploratory learning. Exploitative learning is mainly embodied in the indepth mining and development of existing resources and capabilities possessed by the existing BOP network to carry out innovative activities. For instance, company Y relies on the sales network of supermarket chains to cooperate with multiple online platforms, optimizing and upgrading sales channels. Based on the local logistics network, company $S$ integrated local logistics enterprises to build a comprehensive e-commerce logistics base. Exploratory learning is mainly embodied in exploring new opportunities, discovering and using new resources and abilities to carry out innovative activities. In this case, it is embodied in the enterprise's business expansion into the BOP and the acquisition and utilization of new knowledge and resources in the BOP area. For instance, based on the unique local selenium-rich resources, company $\mathrm{Y}$ has developed and produced "Kang Segu" brand ecological selenium-rich pork and "Chaotianhe" brand pig feed. The Ziyang Se-enriched Ecological Special Tea, jointly developed by Company Z, launched a new product "China Tea Brand Ziyang Se-enriched Maojian". The essential difference between the two is that the former is conducive to the current survival of the enterprise, while the latter emphasizes how to find new opportunities to benefit the long-term development of the enterprises. The results are shown in Table 4. 


\subsection{Dynamic Capability}

BOP offers a suitable context in which to explore the dilemma of business model designs with regard to the adaptation to and shaping of the context because firms are advised to adapt to their context and build on local conditions (Hart and London, 2005) [9]. Simultaneously, firm activities are also expected to radically change the context in which they operate by introducing new products and services (Prahalad and Hammond, 2002) [84]. Teece believes that the dynamic capability of an enterprise is essentially an ability to adapt to the external environment. Drawing on Teece's research, this article divides the dynamic capability into environmental sensing, environmental adaptive, and environmental shaping capability from an environmental perspective [48].

Based on case analysis, our research has identified three dynamic capabilities, namely environmental sensing capability, environmental adaptive capability, and environmental shaping capability. Environmental sensing capability mainly refers to the judgment of business risks and opportunities, research dynamics and changes in market demand, and the ability to quickly respond to the external environment. For example, companies grasp government policies ( $\mathrm{Y}, \mathrm{P}, \mathrm{B}, \mathrm{S}, \mathrm{Z}$, and $\mathrm{M})$, industry development trends and research dynamics $(\mathrm{B}$ and $\mathrm{P})$, business risks and opportunities, market demand, and consumer groups ( $\mathrm{Z}, \mathrm{P}$, and $\mathrm{Y})$ changes, etc. Environmental adaptive capability is mainly reflected in internal and external resource deployment and process or system improvement. For instance, company $\mathrm{Z}$ dispatched an expert technical team to Ziyang to plan and guide, improve the tea planting specifications, optimize the tea production process, and realize the whole process of monitoring from the tea garden to the cup, and control the product quality in the whole process. By optimizing production factors, adopting measures to local conditions, rational planning, and large-scale operations, company $\mathrm{P}$ has promoted large-scale planting and product branding. Environmental shaping capability is mainly composed of supply chain construction and business model innovation. For instance, the construction of the supply chain by company $S$ has promoted innovation in the production, processing, logistics, and catering services of Ziyang's agricultural and sideline products extended the industrial chain, having established local poverty alleviation industrial projects. Company $Y$ has innovated the cooperation model of "Pig Industry Alliance". The company adopts the "pig-methane-fertilizer-vegetable" model of combining planting and breeding, carries out first-class planning, design, and operation management, and forms a benign interaction in the links of capital, technology, management, materials, and sales. The results are shown in Table 5.

Based on the description and analysis of the case data, this study evaluated the relational embeddedness, ambidexterity learning, and dynamic capability of each sample firm based on the actual situation and investigated the interviewees and experts to review and modify it. The five levels of excellent, good, average, poor, and terrible, from high to low, the level of various indicators of the sample firms are shown in Table 6.

Table 6. Relational embeddedness, ambidexterity learning, and dynamic capability level of sample firms.

\begin{tabular}{|c|c|c|c|c|c|c|c|}
\hline & \multicolumn{2}{|c|}{ Relational Embeddedness } & \multicolumn{2}{|c|}{ Ambidexterity Learning } & \multicolumn{3}{|c|}{ Dynamic Capability } \\
\hline & Mutual Trust & $\begin{array}{l}\text { Reciprocity } \\
\text { Norms }\end{array}$ & $\begin{array}{l}\text { Exploitative } \\
\text { Learning }\end{array}$ & $\begin{array}{l}\text { Exploratory } \\
\text { Learning }\end{array}$ & $\begin{array}{l}\text { Sensing } \\
\text { Capability }\end{array}$ & $\begin{array}{l}\text { Adaptive } \\
\text { Capability }\end{array}$ & $\begin{array}{l}\text { Shaping } \\
\text { Capability }\end{array}$ \\
\hline $\mathrm{Y}$ & excellent & excellent & excellent & excellent & excellent & excellent & excellent \\
\hline Z & good & good & excellent & good & good & good & excellent \\
\hline $\mathrm{P}$ & good & excellent & good & average & good & excellent & excellent \\
\hline $\mathrm{B}$ & average & average & average & average & average & average & average \\
\hline S & average & average & good & terrible & average & good & average \\
\hline M & average & average & good & terrible & average & good & average \\
\hline
\end{tabular}

(Source: Own elaboration). 


\section{Discussion and Findings}

In the following, this study will compare and analyze the various sets of variables of all the case companies, so as to summarize the correlation and causality among the variables of relational embeddedness, ambidexterity learning, and dynamic capability, and propose exploratory research propositions.

\subsection{Relational Embeddedness and Ambidexterity Learning}

In the theoretical presupposition, this paper believes that the relational embeddedness in the cooperation networks is closely related to ambidexterity learning. In other words, mutual trust and reciprocity norms are positively related to exploitative learning and exploratory learning. The data results of the case analysis better support this view.

\subsubsection{Mutual Trust and Ambidexterity Learning}

It can be seen from Table 6 that mutual trust is positively related to the exploitative learning and exploratory learning of enterprises. For example, Company Y and Company $\mathrm{Z}$ have established a good relationship of trust with local governments and BOP groups. All parties keep their promises and cooperate with each other for a win-win situation. Compared with other companies in the same industry, network members are more proactive and voluntary to share information and can faster obtain important policy information, market information, and experience know-how, and effectively integrate local resources with the resources and capabilities accumulated by enterprises to develop new technologies, strategies, and models, so as to fully release the value and creative potential of local resources, thereby the lack of resources in the BOP market has turned into multiple opportunities. The degree of trust between company B and its partners in the cooperation network is average. Although it can obtain information supported by government policies, information advantages are not obvious compared with competitors in the industry. Meanwhile, it is not outstanding in the application of new knowledge, existing experience, and know-how in production.

It can be inferred that when there is a good trust relationship in the cooperation network, exchange of technology and market information can often be carried out more quickly and in-depth, which helps to obtain and apply heterogeneous knowledge efficiently. At the same time, to a certain extent, to overcome the obstacles in the process of transmitting tacit knowledge, it is helpful to the transmission of some experience and know-how, so that enterprises can acquire more useful knowledge and skills. Moreover, due to the high degree of mutual trust, it ensures that companies keep their promises, improves the accuracy of information obtained, and speeds up the application of new knowledge to enterprise production and product development.

For example, company $\mathrm{Y}$ trusts the government and farmers in the BOP cooperation network. Cooperating parties keep their promises, and even if there are differences or potential problems, they can communicate and resolve them together as soon as possible. Facing the problem of single breed, under the support of government policy, the company introduced Australian and American live pig breeds, and cooperated with universities to hire professors from universities such as Xinong University and Huazhong Agricultural University, relying on the technical support of universities, hybrid ternary pigs and perfected the construction of live pig breeding system, and realizing the entire process of improving varieties from the original seed farm to the commercial production. Complying with the government's creation of the business card of "selenium-enriched health and ecological health", the company is based on Ankang's unique selenium resources, taps new market demands, and discovers new market opportunities. It is dedicated to postgraduate pig breeding and selenium-enriched pork and feed research and development. Produced "Kang Se Valley" brand ecological selenium-enriched pork and "Chaotianhe" brand live pig feed, which has won unanimous praise from consumers in Shaanxi, Beijing, Guangdong, Sichuan, and other markets for its excellent quality. With the support of the government and Dalian Commodity Exchange (DCE), the company innovated its risk management 
model. The company carried out a pilot project of cost price insurance for pig farm feed (corn, soybean meal) on the DCE, and successfully used "insurance + futures" to avoid the risk of feed cost fluctuations caused by price fluctuations. It can be seen that mutual trust promotes the acquisition and application of local existing knowledge and new knowledge by enterprises, and the mutual trust of all entities in the BOP market can help promote the exploitative and exploratory learning of enterprises.

Through the above analysis, this research puts forward the following propositions:

Proposition 1. The mutual trust in the BOP cooperation network has a positive impact on exploitative learning defined as acquisition or utilization of existing knowledge.

Proposition 2. The mutual trust in the BOP cooperation network has a positive impact on exploratory learning defined as acquisition or utilization of new knowledge.

\subsubsection{Reciprocity Norms and Ambidexterity Learning}

It can be seen from Table 6 that reciprocity norms are positively related to exploratory learning and exploitative learning. For example, company $S$ often goes deep into the BOP cooperation network to carry out mutually beneficial activities, solves problems with the government, and develops skills training for farmers; company P establishes a skill training mechanism for planting Chinese medicinal materials for poor households in Zhashui County to help poor villages build or renovate TongcunTongzu Road, established a good relationship with local farmers, the company makes full use of the rich resources of traditional Chinese medicinal materials in the region, scaled operations, and promoted product branding and large-scale planting. The reciprocity norms of the six companies in the BOP cooperation network have been established, so it has better promoted exploitative learning and exploratory learning.

"When the spring started in March this year, Company P provided us with free honeysuckle seedlings for us to plant. Not only did we promise to buy them at that time, but also paid us back every day when we planted them."

L Local farmers

"In order to help poor local households, get rid of poverty, the planting, weeding, and picking of honeysuckle in the first three years were paid to villagers at the standard of 120 yuan per day, and the company was responsible for nursery fees and fertilizers."

_- Village cadre

It can be inferred that when companies have good reciprocity norms, the cooperation between each other is often more frequent and tacit, and it is easy to produce the willingness and enthusiasm for knowledge sharing. Knowledge is more likely to transfer in cooperation, which is conducive to the transfer and exchange of existing knowledge, and more in-depth new knowledge can also be acquired. Moreover, the reciprocity norms are conducive to learning and imitation among the subjects of the cooperation network, and thus can better and faster apply the acquired new knowledge and existing knowledge to the production activities of the enterprise.

For example, Company $Z$ has established an order-based production and sales partnership with Ziyang's backbone tea companies to increase the value of Ziyang tea's brand and increase the purchase price of fresh leaves for farmers, so that tea farmers can obtain more benefits. Farmers can use the knowledge and skills accumulated in the long-term work to improve the enthusiasm of fresh leaf picking, and quality standards, and provide natural, green, healthy, and safe high-quality raw materials for tea production. Company Z selected Ziyang Maojian among many Ziyang tea products to focus on, combining with China Tea's advanced tea-making technology, and on the basis of referring to the original formula and improving quality, to develop new tea products and jointly develop a new 
product Ziyang selenium-rich Ecological tea special selection-"China Tea Brand Ziyang Selenium-rich Maojian".

Through the above analysis, this research puts forward the following propositions:

Proposition 3. The establishment of reciprocity norms in the BOP cooperation network has a positive impact on exploitative learning defined as acquisition or utilization of existing knowledge.

Proposition 4. The establishment of reciprocity norms in the BOP cooperation network has a positive impact on exploratory learning defined as acquisition or utilization of new knowledge.

\subsection{Ambidexterity Learning and Dynamic Capability}

\subsubsection{Ambidexterity Learning and Environmental Sensing Capability}

It can be seen from Table 6 that there is a positive correlation between corporate ambidexterity learning and environmental sensing capability. For example, company $\mathrm{Y}$, which can acquire a large amount of existing knowledge and new knowledge, has a good environmental sensing at the same time. While company $\mathrm{S}$ and company $\mathrm{M}$ have not acquired much new knowledge, their environmental sensing capability is not ideal.

It can be inferred that enterprises continue to accumulate knowledge and experience through exploitative learning, and repeatedly learn and improve existing knowledge and resources, which will help enterprises capture market knowledge and technological trends timely, and enhance their ability to perceive opportunities and threats. The more the new knowledge and skills an enterprise can acquire through exploratory learning, the broader its problem-solving ideas and the more novel concepts it has. As acquisition and accumulation of relevant knowledge and information in new fields affect companies' recognition and perception of opportunities, the innovative knowledge collected in the past can help companies identify some new technologies emerging in the market today and predict the trends of future technology and market changes. Exploitative learning and exploratory learning deepen the enterprise's understanding of cooperation network processes and practices to innovate, integrate and optimize existing processes and practices based on dynamic environment, and enhance their ability to sense new opportunities and potential risks.

For example, Company Y established an interest link mechanism of "companies, farmers, and poor households" in accordance with the "representative breeding model", and fully relied on the cooperation and support of financial and social parties to integrate all parties' information and resources. In this way, the capital, technology, management, materials, sales, and other links existing in production can form a benign interaction and resource sharing, so as to achieve the common development and common benefit of all parties and form a community of risk guarantee and benefit-sharing. Company $\mathrm{P}$ has increased research and development of new drugs, strengthened research and development cooperation with universities and scientific research institutions, continuously increased investment in R\&D and innovation of new processes, new technologies, and new products, and actively carried out research and development work on new drugs, generic drugs, and major health products. In the process of exploratory learning, the company has gradually realized that it has not yet formed a development model centered on pharmaceutical research and development, its scientific research strength is still relatively weak, its competitiveness is not strong, it cannot occupy a dominant position in the market, and it faces greater operating risks. To this end, the company has increased investment in scientific research and development, changed research and development strategies, innovated product technology, and continuously enriched product categories. Enterprise $\mathrm{P}$ and Enterprise $Y$ have improved their capability to sensing risks through the exploitative learning and exploratory learning within the alliance.

Through the above analysis, this research puts forward the following research propositions: 
Proposition 5. The exploitative learning of enterprises defined as acquisition or utilization of existing knowledge in the BOP cooperation network has a positive impact on the enterprise environmental sensing capability.

Proposition 6. The exploratory learning of enterprises defined as acquisition or utilization of new knowledge in the BOP cooperation network has a positive impact on the enterprise environmental sensing capability.

\subsubsection{Ambidexterity Learning and Environmental Adaptive Capability}

It can be seen from Table 6 that there is a positive influence between exploitative learning, exploratory learning, and environmental adaptive capability. For example, company $S$ actively adapts to the needs of the market and consumers, integrates local logistics companies, and builds a comprehensive e-commerce logistics base of 30,000 square meters that integrates warehousing, transportation, distribution, information exchange, and the trade circulation. This opened up the last mile of express logistics to thousands of households, expanded the sales channels of local characteristic agricultural and sideline products, and created an e-commerce poverty alleviation brand of "orders into mountains, products into cities", and realized "urban-rural convection". Company Z controls high-quality tea resources through the entire industry chain control and the "company + supplier + farmer" operation model, continuously improves the tea picking standards, and continuously improves the quality of fresh tea picking, ensuring the high quality of tea natural, green, healthy, and safe at the source, which effectively guarantees the excellent quality of tea products. After perceiving the new market demand and the trend of younger consumer groups, company $\mathrm{Z}$ dispatched an expert technical team to Ziyang to improve tea planting specifications, optimize the tea production process, realized the whole process of monitoring from the tea garden to the cup, and ensured that the product quality was controlled from the source. While ensuring the quality of excellent tea products, product experience is more personalized and youthful. The two companies have improved their environmental adaptive capability through exploitative learning and exploratory learning.

It can be inferred that through exploitative learning, companies continue to extract and refine existing knowledge and skills in the network, repeatedly strengthen existing technologies, revise their existing resources and knowledge systems, and improve operating practices and skills. While through exploratory learning, companies can get rid of the strong "rigidity" of existing strategies, technologies, and business processes formed by existing experience and practices, overcome corporate inertia and path dependence, make timely adjustments, and be able to quickly respond to the external environment Variety. It can be seen that enterprises have improved their environmental adaptive capability through exploitative learning and exploratory learning.

Through the above analysis, this research puts forward the following research propositions:

Proposition 7. The exploitative learning of enterprises defined as acquisition or utilization of existing knowledge in the BOP cooperation network has a positive impact on the enterprise environmental adaptive capability.

Proposition 8. The exploratory learning of enterprises defined as acquisition or utilization of new knowledge in the BOP cooperation network has a positive impact on the enterprise environmental adaptive capability.

\subsubsection{Ambidexterity Learning and Environmental Shaping Capability}

It can be seen from Table 6 that there is a positive influence between exploitative learning, exploratory learning, and environmental shaping capability.

For example, in order to solve the dilemma of Ankang pig breeding, in the process of long-term exploratory learning, company Y relied on local policy support and characteristic 
resources to innovate an alliance form of "leading enterprise + small and medium-sized enterprise", providing financial support and technical guidance for alliance enterprises, uniformly supply breeding pigs and feed, organizing regular and irregular training, guiding alliance enterprises to update technical assistance, and supporting enterprises to build distinctive brands. Otherwise, cooperating with guarantee companies, it has assisted more than 70 alliance members in financing a total of CNY 800 million from financial institutions such as China Development Bank, Agricultural Development Bank, Minsheng Bank, etc. The shortage of funds for breeding enterprises and difficulties in financing guarantees have been effectively alleviated. In addition, the company also invested CNY 5 million to establish a comprehensive vocational farmer training school, providing free technical training for employees of the alliance and local farmers. Company $Y$ has also innovated in the alliance to adopt a "pig-methane-fertilizer-vegetable" model of the combination of planting and breeding, carrying out first-class planning, design and operation management, and has embarked on a green, economic, circular, and sustainable development path. The production efficiency of the alliance enterprises has been significantly improved, which has promoted the cultivation of professional farmers and promoted the harmonious development of the breeding industry and the environment.

It can be inferred that companies require to respond to the dynamic environment timely through exploitative learning, acquire knowledge related to the organization's existing products or technologies from the network, and continuously shape the environment in the process of deep mining of this knowledge to improve the company's existing resource utilization efficiency, thereby maintaining the existing competitive advantages. At the same time, through exploratory learning, new knowledge obtained is fairly different from its existing knowledge, breaking existing learning paths and conventions, promoting the reorganization and reconstruction of resources, and being able to apply this new knowledge and new skill to product production and design in. This process affects the speed of enterprises' decision-making in an environment full of uncertainties and enhances their capabilities to shape the environment.

Through the above analysis, this research puts forward the following research propositions:

Proposition 9. The exploitative learning of enterprises defined as acquisition or utilization of existing knowledge in the BOP cooperation network has a positive impact on the enterprise shaping capability.

Proposition 10. The exploratory learning of enterprises defined as acquisition or utilization of new knowledge in the BOP cooperation network has a positive impact on the enterprise environmental shaping capability.

\subsection{Relatinal Embeddedness and Dynamic Capability}

\subsubsection{Mutual Trust and Dynamic Capability}

It can be seen from Table 6 that mutual trust has a positive effect on dynamic capabilities. The mutual trust of all entities in the BOP cooperation network helps enterprises to improve their environmental sensing, environmental adaptive, and environmental shaping capabilities. For example, company $\mathrm{Y}$ and company $\mathrm{P}$, which have strong relational embeddedness, both have better dynamic capabilities. Corporate trust relationships enable companies to effectively use internal and external resources, detect changes in the external environment earlier, and improve the accuracy and timeliness of information acquisition, so that opportunities can be identified, evaluated, and seize faster adjusting corporate strategies. The mutual trust of company B and company $\mathrm{M}$ is relatively weak, and their dynamic capabilities are relatively weak.

Therefore, this research puts forward the following proposition: 
Proposition 11. The mutual trust in the BOP cooperation network has a positive impact on the dynamic capability defined as environmental sensing, environmental adaptive, and environmental shaping capabilities.

\subsubsection{Reciprocity Norms and Dynamic Capability}

It can be seen from Table 6 that reciprocity norms have a positive impact on dynamic capability. The establishment of reciprocal norms of each subject in the cooperation network will help enterprises to improve their environmental sensing, environmental adaptive, and environmental shaping capabilities. For example, company $\mathrm{Y}$, company $Z$, and company $P$ have established good reciprocity norms with all entities in the network, getting better environmental sensing, environmental adaptive, and environmental shaping capabilities than other companies.

Therefore, this research puts forward the following proposition:

Proposition 12. The reciprocity norms in the BOP cooperation network have a positive impact on dynamic capability defined as environmental sensing, environmental adaptive, and environmental shaping capabilities.

\section{Conclusions}

To sum up, based on the exploratory case analysis of six Chinese local companies in the BOP cooperation network, this study systematically connects the social network, organizational learning, and dynamic capability theory, revealing the influence path that relationship embeddedness has an effect on the dynamic capabilities of enterprises. It is pointed out that ambidexterity learning is the key intermediary variable of relational embeddedness affecting dynamic capabilities, and the theoretical framework of "relational embeddedness-ambidexterity learning-dynamic capability" is established (as shown in Figure 3). On one hand, this research can expand the current research on antecedent variables of DC. On the other hand, it reveals the mechanism of relational embeddedness, ambidexterity learning, and dynamic capability. Research shows that mutual trust and reciprocity norms can promote the acquisition and utilization of existing knowledge and new knowledge, thereby enhancing enterprise environmental sensing, environmental adaptive, and environmental shaping capabilities.

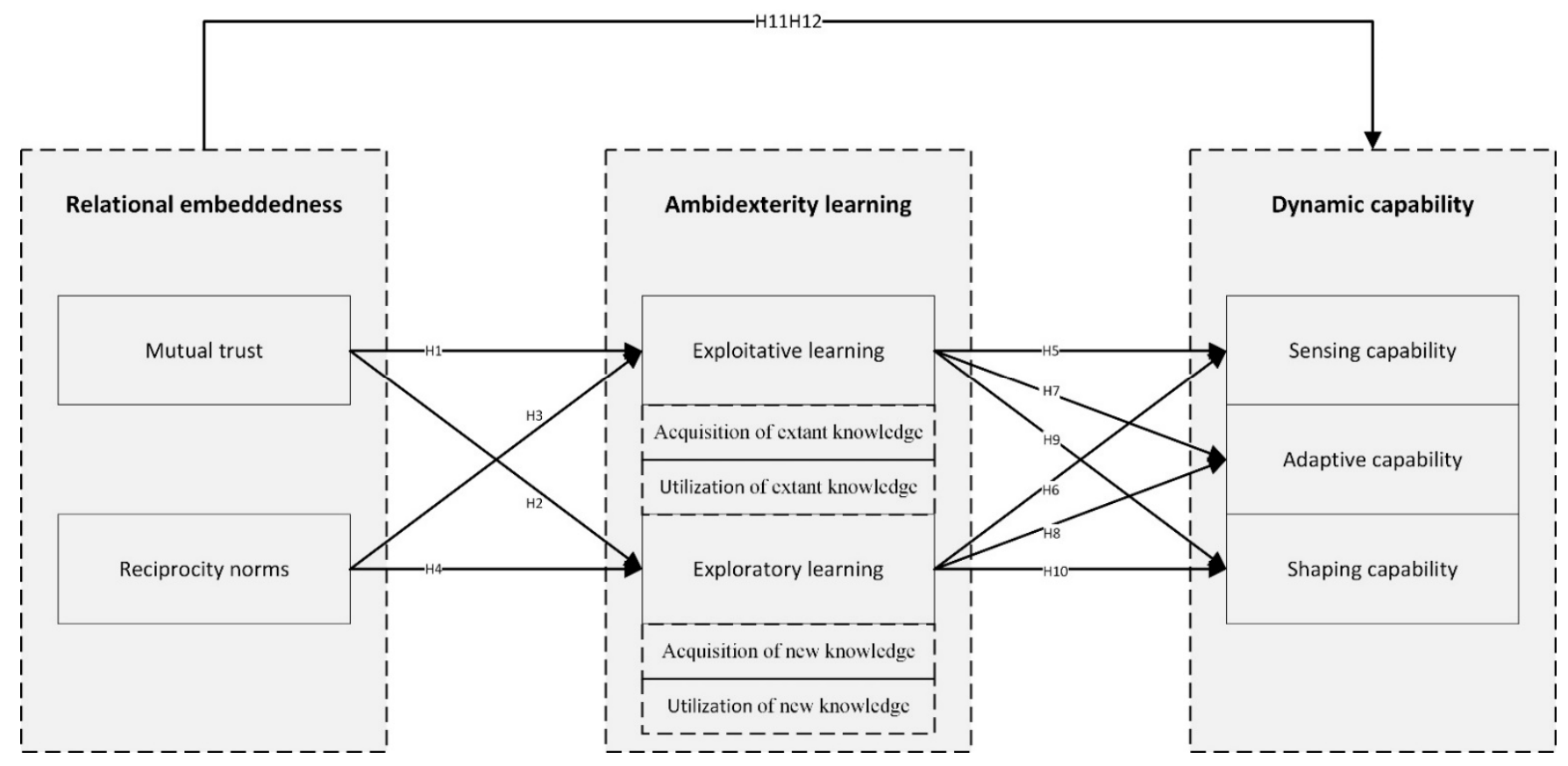

Figure 3. The mechanism of relational embeddedness on dynamic capability. (Source: Own elaboration). 


\subsection{Contributions}

The first contribution implies that this paper constructs a "relational embeddednessambidexterity learning-dynamic capability" research model, taking dynamic capability as the dependent variable, clarifying how relationships affect dynamic capability, and analyzing the influence path of social embeddedness on dynamic capability based on ambidexterity learning theory from a knowledge perspective. The research results subscribe to previous scholars' views on the influence of social embeddedness on dynamic capability, and extends Døving and Gooderham's research on embeddedness on dynamic capability, using ambidexterity learning as an intermediary factor. This validates the research conclusions of Døving and Gooderham [20] that the relational embeddedness and DC are positively correlated in developing countries, providing theoretical guidance for Chinese enterprises to better develop their business in the BOP market.

The second contribution is that in the BOP market, the enterprise DC is split into three dimensions: environmental sensing, environmental adaptive, and environmental shaping capabilities, which provides a new perspective for the study of DC in the future. This offers a necessity for the measurement of DC and the construction of conceptual dimensions of DC. On this basis, the influence path and mechanism of social embeddedness on DC are proposed, and how to build and to improve DC are deeply understood, which expands the research of dynamic capability on organizational performance.

The third contribution challenges the influence mechanism of social embeddedness on DC from a learning perspective and takes ambidexterity learning as an intermediary variable. There have been scholars studying the impact of organizational learning on DC, but ambidexterity learning emphasizes the communication and interaction between enterprises and the external environment, from which perspective few scholars have analyzed the impact of social embeddedness on the construction of dynamic capability. Therefore, the mediating role of ambidexterity learning has theoretical and practical research value for the research of social embeddedness on DC.

Lastly, the paper emphasizes the role of the Chinese government in embedding into the BOP market and building dynamic capabilities. This paper analyzes the local cases in China and obtains a deep understanding of the existing BOP research. Based on the case analysis of the BOP market in China, by embedding in the BOP market, promoting the construction and evolution of cooperation networks among enterprises, BOP groups, governments, and intermediary organizations, the local government is an important factor in promoting the positive interaction of network relations. The research is different from foreign cases that emphasize the core role of NGOs or non-profit organizations in the BOP network, reflecting the characteristics of the Chinese contextual BOP market, and contributes new content.

\subsection{Limitations and Future Research}

Our study does have some limitations. As with any research project, the choices that we made in this study lead to limitations in the interpretation of our findings. Although this study followed standard procedures, in order to improve the reliability and validity of the study, the triangulation method also is adopted, there are still some restrict factors such as researchers' subjective judgment in the research process, so the conclusion may be biased to a certain extent.

Firstly, subsequent empirical research methods can be used to quantitatively analyze the influence of social embeddedness and ambidexterity learning on dynamic capability. An empirical analysis of the different effects of different levels of social embeddedness. This is because related studies have proved that the relationship between the survival and development of an enterprise and the social network it is embedded in has an inverted U-shaped relationship curve. The relationship between the two is too close and too loose, and it will reduce the company survival rate (Uzzi, 1997) [28]. It is also possible to comprehensively consider the interactive influence of the embeddedness of the relationship and the embeddedness of the structure of the enterprise in the network and deepen the discus- 
sion on the mechanism of the embeddedness of the network affecting the ambidexterity learning behavior of the enterprise, and then the dynamic capability.

Secondly, exploitative and exploratory learning play an important role in constructing DC. Therefore, the mediating effect of interaction and balance between exploratory learning and utilization learning can be future studied.

The last but not the least, the BOP innovation network is divided into different levels. Eisenhardt and Martin [56] and Zollo and Winter [49] believe that the influencing factors of dynamic capability can exist at the enterprise level, as well as at the individual and network levels. Levels-of-analysis issues are especially relevant for network researchers, whose research questions usually lie at the intersection between different levels. Some scholars have conducted research on the cross-level perspective of the BOP innovation network, and future research should explore more cross-level perspectives to explore the impact of BOP market social embeddedness on DC mechanism.

Author Contributions: Conceptualization, Y.Z. and W.Z.; Funding acquisition, W.Z.; Investigation, Y.Z. and W.Z.; Methodology, Y.Z.; Project administration, J.L. and W.Z.; Resources, J.L. and W.Z.; Supervision, J.L. and W.Z.; Writing-original draft, Y.Z.; Writing-review and editing, Y.Z. and W.Z. All authors have read and agreed to the published version of the manuscript.

Funding: This work was funded by the Department of science and technology of Shaanxi Province and Shaanxi Association for Science and Technology, grant numbers E219060016.

Institutional Review Board Statement: Not applicable.

Informed Consent Statement: Not applicable.

Data Availability Statement: Data available on request.

Conflicts of Interest: The authors declare no conflict of interest.

\section{References}

1. World Bank Statistics. 2019. Available online: http://povertydata.worldbank.org/poverty/country/CHN (accessed on 18 February 2017).

2. Shah, A. Poverty Facts and Stats Global Issues. Available online: http://www.Globalissues.org/article/26/poverty-facts-andstats (accessed on 21 February 2017).

3. Ansari, S.; Munir, K.; Gregg, T. Impact at the bottom of the pyramid: The role of social capital in capability development and community empowerment. J. Manag. Stud. 2012, 49, 813-842. [CrossRef]

4. Khavul, S.; Bruton, G.D. Harnessing innovation for change: Sustainability and poverty in developing countries. J. Manag. Stud. 2013, 50, 285-306. [CrossRef]

5. London, T.; Hart, S.L. Reinventing strategies for emerging markets: Beyond the transnational model. J. Int. Bus. Stud. 2004, 35, 350-370. [CrossRef]

6. Prahalad, C.K.; Hart, S.L. Fortune at the bottom of the pyramid. Strategy Bus. 2002, 26, 2-14. [CrossRef]

7. Slawinski, N.; Bansal, P. A matter of time: The temporal perspectives of organizational responses to climate change. Organ. Stud. 2012, 33, 1537-1563. [CrossRef]

8. Kantar Research Report. China: The Neglected Bottom of the Pyramid available. 2015. Available online: https://www. kantarworldpanel.com/global/News/China-The-neglected-bottom-of-the-pyramid (accessed on 18 February 2017).

9. Hart, S.L.; London, T. Developing Native Capability. What Multinational Corporations Can Learn from the Base of the Pyramid. Stanf. Soc. Innov. Rev. 2005, 3, 28-33.

10. Alvarez, S.A.; Barney, J.B. Can organizing a firm create new economic value? In Entrepreneurial Strategies: New Technologies in Emerging Markets; Cooper, A.C., Alvarez, S.A., Carrera, A.A., Mesquita, L.F., Vassolo, R.O., Eds.; Blackwell Publishing: Malden, MA, USA, 2006; pp. 11-25.

11. Kolk, A.; Rivera-Santos, M.; Rufín, C. Reviewing a decade of research on the "base/bottom of the pyramid" (BOP) concept. Bus. Soc. 2014, 53, 338-377. [CrossRef]

12. Khanna, T.; Palepu, K.G.; Sinha, J. Strategies that fit emerging markets. Harv. Bus. Rev. 2005, 83, 2-18.

13. Hart, S.L. BOP 2.0: The next generation of strategy for the base of the pyramid. In Corporate Stewardship: Achieving Sustainable Effectiveness; Routledge: London, UK, 2015.

14. Webb, J.W.; Kistruck, G.M.; Ireland, R.D.; Ketchen, J.D.J. The entrepreneurship process in base of the pyramid markets: The case of multinational enterprise/ nongovernment organization alliances. Entrep. Theory Pract. 2010, 34, 555-581. [CrossRef]

15. De Soto, H. They Mystery of Capital: Why Capitalism Triumphs in the West and Fails Everywhere Else; Bantam Press: London, UK, $2000 ;$ p. 276. 
16. Brugmann, J.; Prahalad, C.K. Cocreating business's new social compact. Harvard Bus. Rev. 2007, 85, 80-90.

17. Clarke, A.; Fuller, M. Collaborative Strategic Management: Strategy Formulation and Implementation by Multi-Organizational Cross-Sector Social Partnerships. J. Bus. Ethics. 2010, 94, 85-101. [CrossRef]

18. Rufin, C.R.; Rivera-Santos, M. Between Commonweal and Competition: Understanding the Governance of Public-Private Partnerships. J. Manag. 2012, 38, 1634-1654. [CrossRef]

19. Ramachandran, J.; Pant, A.; Pani, S.K. Building the BOP Producer Ecosystem: The Evolving Engagement of Fabindia with Indian Handloom Artisans. J. Prod. Innovat. Manag. 2011, 29, 33-51. [CrossRef]

20. Døving, E.; Gooderham, P.N. Dynamic capabilities as antecedents of the scope of related diversification: The case of small firm accountancy practices. Strateg. Manag. J. 2008, 29, 841-857. [CrossRef]

21. Forkmann, S.; Henneberg, S.C.; Mitrega, M. Capabilities in business relationships and networks: Research recommendations and directions. Ind. Market. Manag. 2018, 74, 4-26. [CrossRef]

22. Zeevik, G.; Yanay, F.; Eli, G. Embeddedness and growth of small businesses in rural regions. J. Rural. Stud. 2018, 62, 174-182.

23. Dyer, J.H. Does Governance Matter? Keiretsu Alliances and Asset Specificity as Sources of Japanese Competitive Advantage. Organ. Sci. 1996, 7, 649-666. [CrossRef]

24. Dyer, J.H.; Hatch, N.W. Relation-specific capabilities and barriers to knowledge transfers: Creating advantage through network relationships. Strateg. Manag. J. 2006, 27, 701-719. [CrossRef]

25. Lashitew, A.A.; Bals, L.; van Tulder, R. Inclusive Business at the Base of the Pyramid: The Role of Embeddedness for Enabling Social Innovations. J. Bus. Ethics. 2020, 162, 421-448.

26. Polanyi, K.; Moiseev, N.A.; Von Gadow, K. The Great Transformation: The Political and Economic Origins of Our Time. P. Natl. Acad. Sci. 2015, 104, 5953-5958.

27. Granovetter, M. Economic Action and Social Structure. The Problem of Embeddedness. Am. J. Sociol. 1985, 91, 481-510. [CrossRef]

28. Uzzi, B. Social Structure and Competition in Interfirm Networks: The Paradox of Embeddedness. Admin. Sci. Quart. 1997, 42, 35-67. [CrossRef]

29. Gulati, R. Network location and learning: The influence of network resources and firm capabilities on alliance formation. Strateg. Manag. J. 1999, 20, 397-420. [CrossRef]

30. Nahapiet, J.; Ghoshal, S. Social capital, intellectual capital, and the organizational advantage. Acad. Manag. Rev. 1998, 23, 242-266. [CrossRef]

31. Hansen, M.T. The search-transfer problem: The problem of weak ties in sharing knowledge across organization units. Admin. Sci. Quart. 1999, 44, 82-111. [CrossRef]

32. Levin, D.Z.; Cross, R. The Strength of Weak Ties You Can Trust: The Mediating Role of Trust in Effective Knowledge Transfer. Manag. Sci. 2002, 50, 1477-1490. [CrossRef]

33. Das, T.K. The Dynamics of Alliance Conditions in the Alliance Development Process. J. Manag. Stud. 2002, 39, 725-746. [CrossRef]

34. Uzzi, B.; James, J.; Gillespie. Knowledge Spillover in Corporate Financing Networks: Embeddedness and the Firm's Debt Performance. Strateg. Manag. J. 2002, 23, 595-618. [CrossRef]

35. Borgatti, S.P. Network analysis in the social sciences. Science 2009, 324, 465. [CrossRef]

36. Kale, P.; Singh, H.; Perlmutter, H. Learning and protection of proprietary assets in strategic alliances: Building relational capital. Strateg. Manag. J. 2000, 21, 217-237. [CrossRef]

37. Uzzi, B. The sources and consequences of embeddedness for the economic performance of organizations: The network effect. Am. Sociol. Rev. 1996, 61, 674-698. [CrossRef]

38. Dyer, J.H.; Chu, W. The role of trustworthiness in reducing transaction costs and improving performance: Empirical evidence from the United States, Japan, and Korea. Organ. Sci. 2012, 14, 57-68. [CrossRef]

39. Iacono, S.L. Does community social embeddedness promote generalized trust? An experimental test of the spillover effect. Soc. Sci. Res. 2018, 73, 126-145. [CrossRef]

40. Nyamrunda, F.C.; Freeman, S. Strategic agility, dynamic relational capability and trust among SMEs in transitional economies. J. World. Bus. 2021, 56, 101175. [CrossRef]

41. Johanson, J.; Vahlne, J.E. Markets as networks: Implications for strategy-making. J. Acad. Mark. Sci. 2011, 39, 484-491. [CrossRef]

42. Granovetter, M. The Strength of Weak Ties. Am. J. Sociol. 1973, 78, 1360-1380. [CrossRef]

43. Putnam, R.D. The Prosperous Community: Social Capital and Public Life. Am. Prospect. 1993, 13, 35-42.

44. Burt, R. Structural Holes: The Social Structure of Competition; Harvard University Press: Boston, MA, USA, 1992.

45. Chiu, C.M.; Hsu, M.H.; Wang, E.T.G. Understanding Knowledge Sharing in Virtual Communities: An Integration of Social Capital and Social Cognitive Theories. Decis Support Syst. 2006, 42, 1872-1888. [CrossRef]

46. Wasko, M.M.; Fara, J.S. Why Should I Share? Examining Social Capital and Knowledge Contribution in Electronic Networks of Practice. Mis. Quart. 2005, 29, 35-57. [CrossRef]

47. Teece, D.; Pisano, G. The Dynamic Capabilities of Firms: An Introduction. Ind. Corp. Chang. 1994, 3, 537-556. [CrossRef]

48. Teece, D.; Pisano, G.; Shuen, A. Dynamic capabilities and strategic management. Strateg. Manag. J. 1997, 18, 509-533. [CrossRef]

49. Zollo, M.; Winter, S.G. Deliberate Learning and the Evolution of Dynamic Capabilities. Organ. Sci. 2002, 13, 339-351. [CrossRef]

50. Wang, C.L.; Ahmed, P.K. Dynamic capabilities: A review and research agenda. Int. J. Manag. Rev. 2007, 9, 31-51. [CrossRef]

51. Wu, L.Y. Applicability of the resource-based and dynamic-capability views under environmental volatility. J. Bus. Res. 2010, 63, 27-31. [CrossRef] 
52. Bowman, C.; Ambrosini, V. How the resource-based and the dynamic capability views of the firm inform corporate-level strategy. Brit. J. Manag. 2003, 14, 289-304. [CrossRef]

53. Monferrer, D.; Blesa, A.; Ripoll é s, M. Born globals trough knowledge-based dynamiccapabilities and network market orientation. Bus. Res. Q. 2015, 18, 18-36.

54. Dixon, S.; Meyer, K.; Day, M. Building Dynamic Capabilities of Adaptation and Innovation: A Study of Micro-Foundations in a Transition Economy. Long Range Plan. 2014, 47, 186-205. [CrossRef]

55. Liu, L.N.; Yu, B.; Wu, W.W. The Formation and Effects of Exploitative Dynamic Capabilities and Explorative Dynamic Capabilities: An Empirical Study. Sustainability. 2019, 11, 2581. [CrossRef]

56. Eisenhardt, K.M.; Martin, J.A. Dynamic capabilities: What are they. Strateg. Manag. J. 2000, 21, 1105-1122. [CrossRef]

57. Galunic, D.C.; Eisenhardt, K.M. Architectural innovation and modular corporate forms. Acad. Manag. J. 2001, 44, 1229-1249.

58. Bruni, D.S.; Verona, G. Dynamic Marketing Capabilities in Science-based Firms: An Exploratory Investigation of the Pharmaceutical Industry. Soc. Sci. Electron. Publ. 2010, 20, S101-S117. [CrossRef]

59. Danneels, E. Organizational antecedents of second-order competences. Strateg. Manag. J. 2008, 29, 519-543. [CrossRef]

60. Eikelenboom, M.; Jong, G.D. The Impact of Dynamic Capabilities on SME Sustainable Performance. J. Clean. Prod. 2019, 235, 1360-1370. [CrossRef]

61. Alinaghian, L.; Razmdoost, K. How do network resources affect firms' network-oriented dynamic capabilities? Ind. Mark. Manag. 2017, 71, 79-94. [CrossRef]

62. Teece, D.J. Explicating dynamic capabilities: Nature and microfoundation. Strateg. Manag. J. 2007, 28, 1319-1350. [CrossRef]

63. Ferreira, J.; Coelho, A.; Moutinho, L. Dynamic capabilities, creativity and innovation capability and their impact on competitive advantage and firm performance: The moderating role of entrepreneurial orientation. Technovation 2018, 92, 102061. [CrossRef]

64. Ausrød, V.L.; Vivek Sinha, V.; Widding, Ø. Business model design at the base of the pyramid. J. Clean. Prod. 2017, 162, 982-996. [CrossRef]

65. Chakravarthy, B.S. Adaptation: A Promising Metaphor for Strategic Management. Acad. Manag. Rev. 1982, 7, 35-44. [CrossRef]

66. Miles, R.E.; Snow, C.C.; Meyer, A.D. Organizational Strategy, Structure, and Process. Acad. Manag. Rev. 1978, 3, 546-562. [CrossRef]

67. Sanchez, R. Strategic flexibility in product competition. Strateg. Manag. J. 1995, 16, 135-160. [CrossRef]

68. Cohen, W.M.; Levinthal, D.A. Absorptive Capacity: A New Perspective on Learning and Innovation. Soc. Sci. Electron. Publ. 1990, 35, 128-152. [CrossRef]

69. Easterby-Smith, M.; Prieto, I.M. Dynamic Capabilities and Knowledge Management: An Integrative Role for Learning? Brit. J. Manag. 2008, 19, 235-249. [CrossRef]

70. Wang, L.L.; Gao, Y. Competition network as a source of competitive advantage: The dynamic capability perspective and evidence from China. Long Range Plann. 2020, 54, 102052. [CrossRef]

71. Lin, Y.; Wu, L.Y. Exploring the role of dynamic capabilities in firm performance under the resource-based view framework. J. Bus. Res. 2014, 67, 407-413. [CrossRef]

72. Eriksson, T. Processes, antecedents and outcomes of dynamic capabilities. Scand. J. Manag. 2004, 30, 65-82. [CrossRef]

73. Samina, K. Business Unit Reorganization and Innovation in New Product Markets. Manag. Sci. 2009, 55, 1237-1254.

74. McKelvie, A.; Davidsson, P. From Resource Base to Dynamic Capabilities: An Investigation of New Firms. Br. J. Manag. 2009, 20, S63-S80. [CrossRef]

75. Harris, M.L.; Collins, R.W.; Hevner, A.R. Control of Flexible Software Development under Uncertainty. Inform. Syst. Res. 2009, 20, 400-419. [CrossRef]

76. March, J.G. Exploration and Exploitation in Organizational Learning. Organ. Sci. 1991, 2, 71-87. [CrossRef]

77. Lee, C.Y.; Wu, H.L.; Liu, C.Y. Contextual Determinants of Ambidextrous Learning: Evidence from Industrial Firms in Four Industrialized Countries. IEEE. T. Eng. Manag. 2013, 60, 529-540. [CrossRef]

78. Holmqvist, M. A dynamic model of intra- and inter-organizational learning. Organ. Stud. 2003, 24, 95. [CrossRef]

79. Holmqvist, M. Experiential learning processes of exploitation and exploration within and between organisations: An empirical study of product development. Organ. Sci. 2004, 15, 70-81. [CrossRef]

80. McGrath, R.G. Exploratory Learning, Innovative Capacity, and Managerial Oversight. Acad. Manag. J. 2001, 44, 118-131.

81. Michelino, F.; Cammarano, A.; Celone, A.; Caputo, M. The linkage between sustainability and innovation performance in IT hardware sector. Sustainability 2019, 11, 4275. [CrossRef]

82. Lee, M.T.; Raschke, R.L. Innovative sustainability and stakeholders' shared understanding: The secret sauce to "performance with a purpose". J. Bus. Res. 2020, 108, 20-28. [CrossRef]

83. Zott, C. Dynamic capabilities and the emergence of intraindustry differential firm performance: Insights from a simulation study. Strateg. Manag. J. 2003, 24, 97-125. [CrossRef]

84. Prahalad, C.K.; Hammond, A. Serving the world's poor, profitably. Harv. Bus. Rev. 2002, 80, 48-57.

85. Eisenhardt, K.M. Building Theories from Case Study Research. Acad. Manag. Rev. 1989, 14, 532-550.

86. Hartley, J. Case Study Research. Essential Guide to Qualitative Methods in Organizational Research; Sage Publication: London, UK, 2004.

87. Ghauri, P.N.; Grønhaug, K. Research Methods in Business Studies: A Practical Guide; Pearson Education: London, UK, 2005.

88. Flick, U. An Introduction to Qualitative Research; Sage Publication: Thousand Oaks, CA, USA, 2009. 
89. Yin, R.K. Case Study Research: Design and Methods, 4th ed.; Sage Publications: Thousand Oaks, CA, USA, 2009.

90. Herriott, R.E.; Firestone, W.A. Multisite Qualitative Policy Research in Education: Some Design and Implementation Issues. ERIC Clgh. 1983, 12, 14-19.

91. Hillebrand, B.; Kok, R.A.W.; Biemans, W.G. Theory-testing using case studies. Ind. Market. Manag. 2001, 30, 651-657. [CrossRef]

92. Patton, M.Q. Qualitative Research and Evaluation Methods, 4th ed.; Sage Publications: Thousand Oaks, CA, USA, 2015.

93. Helfat, C.E.; Finkelstein, S.; Mitchell, W.; Peteraf, M.A.; Singh, H.; Teece, D.J.; Winter, S. Dynamic Capabilities: Understanding Strategic Change in Organizations; Blackwell Publishing: Malden, MA, USA, 2007.

94. Smart, P.; Bessant, J.; Gupta, A. Towards technological rules for designing innovation networks: A dynamic capabilities view. Int. J. Oper. Prod. Man. 2007, 27, 1069-1092. [CrossRef]

95. Yin, R.K. Applications of Case Study Research, 2nd ed.; Sage Publications: Thousand Oaks, CA, USA, 2002.

96. Yin, R.K. Case Study Research: Design and Methods, 2nd ed.; Sage Publications: Thousand Oaks, CA, USA, 1994.

97. Flanagan, J.C. The critical incident technique. Psychol. Bull. 1954, 51, 327-358. [CrossRef] [PubMed]

98. Glaser, B.G. Basics of Grounded Theory Analysis; Sociology Press: Mill Valley, CA, USA, 1992.

99. Strauss, A.; Corbin, J. Basics of Qualitative Research Techniques and Procedures for Developing Grounded Theory, 1st ed.; Sage Publications: London, UK, 1990.

100. Jantunen, S.; Gause, D.C. Using a grounded theory approach for exploring software product management challenges. J. Syst. Softw. 2014, 95, 32-51. [CrossRef]

101. Goulding, C. Grounded Theory: A Practical Guide for Management, Business and Market Researchers; Sage Publications: London, UK, 2002.

102. Strauss, A.L.; Corbin, J.M. Basics of Qualitative Research: Techniques and Procedures for Developing Grounded Theory, 2nd ed.; Sage Publications: Thousand Oaks, CA, USA, 1998.

103. Kroeger, T.A.; Davidson, N.J.; Cook, S.C. Understanding the characteristics of quality for software engineering processes: A Grounded Theory investigation. Inform. Softw. Tech. 2014, 56, 252-271. [CrossRef]

104. Gupta, A.K.; Smith, K.G.; Shalley, C.E. The Interplay Between Exploration and Exploitation. Acad. Manag. J. 2006, 49, 693-706. [CrossRef] 